\title{
Influence of Metal Ions on Ruminal Enzyme Activities
}

\author{
Z. FAIXOVÁ ${ }^{1}, \check{S}$. FAIX ${ }^{2}$ \\ ${ }^{1}$ Department of Pathological Anatomy, Physiology and Genetics, University of Veterinary Medicine, Košice, \\ ${ }^{2}$ Institute of Animal Physiology, Slovak Academy of Sciences, Košice, Slovak Republic \\ Received July 16, 2002 \\ Accepted November 18, 2002 \\ Abstract \\ Faixová Z., Š. Faix: Influence of Metal Ions on Ruminal Enzyme Activities. Acta Vet. Brno \\ 2002, 71: 451-455. \\ In vitro incubation experiments were conducted to evaluate the influence of several metal ions \\ on urease, alanine aminotransferase (ALT), aspartate aminotransferase (AST), gamma- \\ glutamyltransferase (GGT) and glutamate dehydrogenase (GDH) enzyme activities of rumen fluid. \\ Rumen fluid was collected from eight fistulated ewes and strained through a cheesecloth. \\ Magnesium, copper and cadmium were each added to $10 \mathrm{ml}$ of rumen fluid to obtain final \\ concentrations of $5 \mathrm{mmol} \cdot \mathrm{l}^{-1}$. After the addition of each metal ion, the mixture was shaken and \\ incubated for $30 \mathrm{~min}$ at $37{ }^{\circ} \mathrm{C}$ prior to enzyme activity assay in the rumen fluid with or without \\ metal ions using spectrophotometric methods. Cadmium was found to inhibit urease, GDH, and \\ GGT activity but on the other hand, it stimulated ALT and AST activity. Copper inhibited both \\ GDH and urease activity with no significant differences for ALT, AST and GGT. Magnesium had \\ stimulatory effect on activity of GGT and GDH. The results of this experiment indicate that metal \\ ions copper, cadmium, and magnesium each affect some ruminal enzyme activity which play an \\ important role in metabolism of nitrogenous substances and may further alter the nitrogen \\ metabolism in the rumen of sheep. \\ Copper, cadmium, magnesium, ruminal enzyme, nitrogen metabolism, rumen, urease
}

Nutritional requirements of ruminants are different from those of monogastric animals. Rumen microbes can synthesize enough amino acids and peptides from the inorganic nitrogen in ammonia or other nitrogen source and carbon skeletons and sulphur precursors. Ammonia assimilation by rumen microbes depends on rumen $\mathrm{pH}$ (Veth et al. 1999), rumen ammonia concentration (Mehrez et al. 1977) and ruminal ammonia-assimilating enzyme activity.

Several ammonia-assimilation reactions by rumen bacteria are known. Enzyme glutamate dehydrogenase plays an important role in maintaining the balance between ammonia- and $\alpha$-amino-nitrogen of the rumen. Alanine represents the amino acid found in the highest concentration in the intracellular pool of free amino acid rumen bacteria. Rumen bacteria possess effective mechanisms for alanine synthesis from ammonia (e.g., alanine dehydrogenase and alanine aminotransferase). Both alanine aminotransferase and aspartate aminotransferase belong to the most common transaminases in the rumen. Glutamate concentration by rumen bacteria depends on gamma-glutamyltransferase activity. This enzyme plays an important role in some peptide and amino acid tranfers through the rumen wall and in the formation of an intracellular pool of glutamate as well.

In the recent past, factories producing copper and mercury have altered the agricultural environment. Jenčík et al. (2001) reported that soil and plant biomass sample analyses from localities situated maximally $10 \mathrm{~km}$ from the copper and formerly mercury producing factories showed significant soil and biomass contamination by mercury, lead, cadmium, copper, and zinc ions. Magnesium-processing industry pollutes its surounding by magnesium fly ash which may increase the risk of oversupply of this ion for exposed animals.

Address for correspondence:

Doc. MVDr. Zita Faixová PhD.

Department of Pathological Anatomy, Physiology and Genetics

Komenséno 73,04181 Medicine
Phone: ++421556325841

Fax: ++4215563236 66

http://www.vfu.cz/acta-vet/actavet.htm 
Many papers have dealt with the study of the effectiveness of various agents on the ruminal activity of several enzymes. Copper, zinc and cadmium ions were found to inhibit urease in the rumen fluid of ewes in an in vitro experiment whereas barium, nickel and manganese appeared to be slightly stimulatory (Spears and Hatfield 1978). Pal et al. (1998) stated that ammonia-nitrogen, trichloracetic acid-soluble nitrogen, urease activity, plasma protein, and urea levels were significantly lower in defauned animals. Results from another study showed that long-term administration of feed contamined with low concentrations of heavy metals may affect microbial synthesis in the rumen and thus ruminant productivity (Legáth et al. 1990).

The objective of the present study was to determine whether addition of various metal ions causing air, soil and biomass contamination in industrially exposed areas would affect some enzyme activities of the rumen fluid.

\section{Materials and Methods}

Rumen fluid was obtained from eight fistulated ewes (Ovis aries) weighing between 30 to $35 \mathrm{~kg}$ in the morning two hours after feeding. The animals were housed individually, fed twice daily, and had free access to water. The total daily ration of each sheep consisted of $400 \mathrm{~g}$ of mixed diet (containing $12 \%$ beetroot molasses, $12 \%$ oats, $48 \%$ wheat and rye bran, $12 \%$ mixed meal and $2 \%$ mineral supplement) and $1000 \mathrm{~g}$ of hay providing $1177.6 \mathrm{~g}$ of dry matter, $23.2 \mathrm{~g}$ of total nitrogen and $6.48 \mathrm{MJ}$ of net energy of lactation.

Throughout the experiment, the animals were maintained according to the principles governing the care of laboratory animals.

The rumen fluid was not collected until the donor animal had received the diet for at least 40 days. After being strained through four layers of cheesecloth, copper, cadmium, and magnesium were separately added to $10 \mathrm{ml}$ of rumen fluid so that their final concentrations were $5 \mathrm{mmol} \cdot \mathrm{l}^{-1}$. All metal ions were added in the chloride form. After the addition of the metal ion, each mixture was shaken and incubated for $30 \mathrm{~min}$ at $37^{\circ} \mathrm{C}$ prior to assaying enzymatic activity in the rumen fluid with or without metal ions.

Alanine aminotransferase, aspartate aminotransferase, gamma-glutamyltransferase, glutamate dehydrogenase and urease activity were determined by the colorimetric methods using spectrophotometric kits produced by Lachema Diagnostica Brno, Czech Republic.

The results are given as the mean \pm SEM. Statistical significance of the differences between values was determined by Student's $t$-test.

\section{Results}

Fig. 1 shows the effect of magnesium, copper and cadmium on the activity of several enzymes of rumen fluid. Comparison of the activity of individual enzymes of the rumen fluid without and with magnesium showed that magnesium stimulated both glutamate dehydrogenase $(0.147 \pm$ 0.007 to $\left.0.277 \pm 0.012 \mu \mathrm{kat}^{-1} \mathrm{I}^{-1}, P<0.001\right)$ and gamma-glutamyltransferase activity $(1.10 \pm$ 0.044 to $\left.1.40 \pm 0.058 \mu \mathrm{kat} \cdot \mathrm{l}^{-1}, P<0.01\right)$ with no significant differences for ALT $(0.39 \pm 0.017$ to $\left.0.42 \pm 0.022 \mu \mathrm{kat} \cdot \cdot^{-1}, \mathrm{NS}\right)$ and AST $\left(0.85 \pm 0.045\right.$ to $\left.0.91 \pm 0.031 \mu \mathrm{kat} \cdot \mathrm{l}^{-1}, \mathrm{NS}\right)$.

Copper significantly decreased activity of glutamate dehydrogenase $(0.147 \pm 0.007$ to $\left.0.056 \pm 0.003 \mu \mathrm{kat} \cdot \mathrm{l}^{-1}, P<0.001\right)$ but did not affect the activity of ALT $(0.42 \pm 0.01$ to 0.43 $\left.\pm 0.02 \mu \mathrm{kat} \cdot \mathrm{l}^{-1}, \mathrm{NS}\right)$, AST $\left(0.87 \pm 0.041\right.$ to $0.94 \pm 0.031 \mu \mathrm{kat} \cdot \mathrm{l}^{-1}$, NS $)$ and GGT $(1.10 \pm 0.044$ to $1.20 \pm 0.0478 \mu \mathrm{kat} \cdot \mathrm{l}^{-1}$, NS).

The effect of cadmium was significantly achieved in ALT, AST, GGT and GDH. It was found that cadmium inhibited glutamate dehydrogenase $(0.147 \pm 0.007$ to $0.075 \pm 0.009$ $\mu$ kat $\left.\cdot{ }^{-1}, P<0.001\right)$ and gamma-glutamyltransferase activity $(1.10 \pm 0.044$ to $0.92 \pm 0.018$ $\left.\mu \mathrm{kat} \cdot \mathrm{I}^{-1}, P<0.05\right)$ and on the other hand it stimulated alanine aminotransferase $(0.43 \pm 0.007$ to $\left.0.520 .032 \mu \mathrm{kat} \cdot \mathrm{l}^{-1}, P<0.05\right)$ and aspartate aminotransferase activity $(0.88 \pm 0.043$ to 1.1 $\left.\pm 0.076 \mu \mathrm{kat} \cdot \mathrm{l}^{-1}, P<0.01\right)$.

The urease activity was significantly lower after copper (14.86 \pm 1.81 to $3.38 \pm 0.91$ nkat $\left.\cdot \mathrm{ml}^{-1}, P<0.001\right)$ and cadmium $\left(14.34 \pm 3.93\right.$ to $\left.2.54 \pm 0.35 \mathrm{nkat} \cdot \mathrm{ml}^{-1}, P<0.01\right)$ treatment and no significant differences were found in magnesium supplement (12.11 \pm 3.63 to 15.33 $\left.\pm 5.04 \mathrm{nkat} \cdot \mathrm{ml}^{-1}, \mathrm{NS}\right)$. 

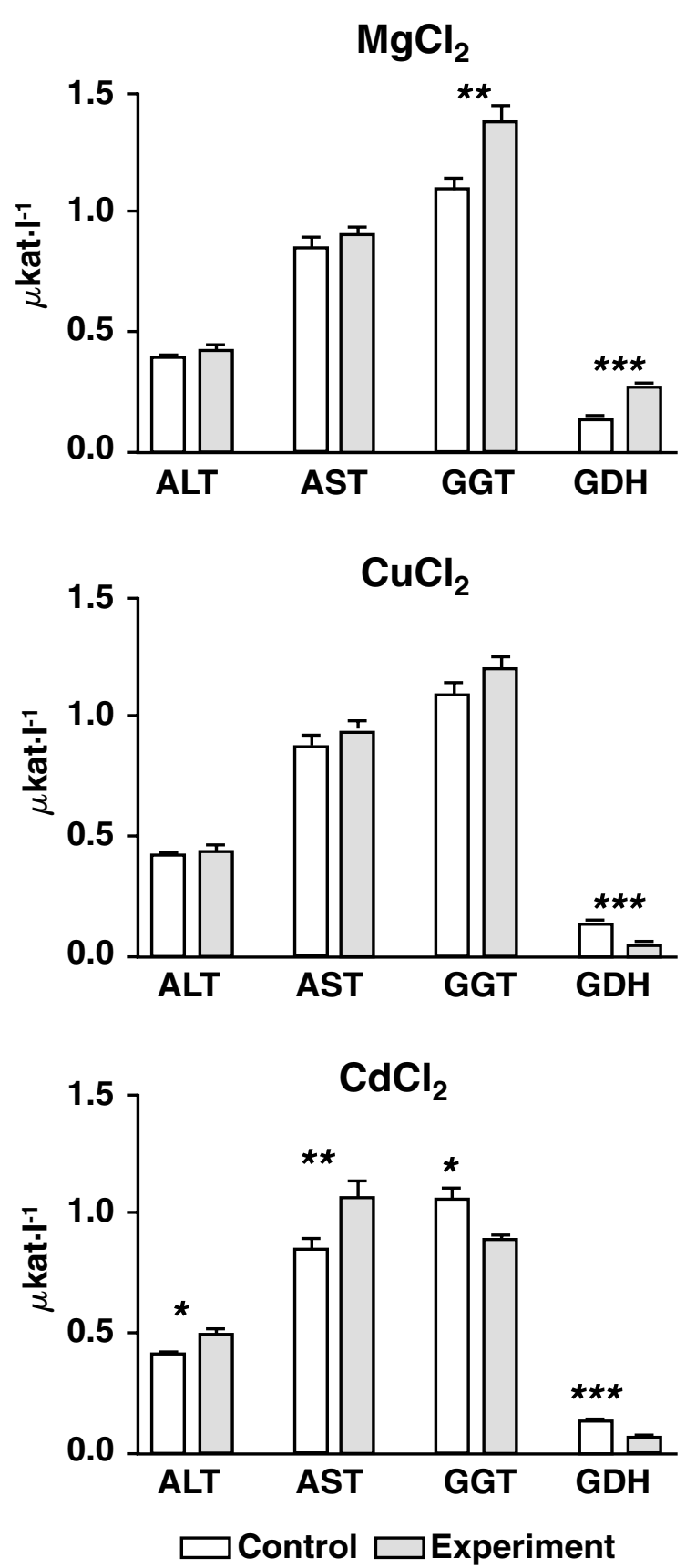

Fig. 1. The influence of magnesium, copper and cadmium on alanine aminotransferase-ALT, aspartate aminotransferase-AST, gammaglutamyl transferase-GGT and glutamate dehydrogenase-GDH activities in rumen fluid. Values are means S.E.M., $\mathrm{n}=8$. Significance: $* P<0.05, * * P<0.01$, $* * * P<0.001$.

\section{Discussion}

Our results showed that metal ions could affect activity of several rumen enzymes. Data from our study indicate that magnesium stimulated the activity of all enzymes tested whereas the cadmium and copper effect is enzyme-specific. Magnesium is a cofactor in various reactions related to carbohydrate, lipid, and protein metabolism. It participates in oxidative phosphorylation and transphosphorylation reactions, cell adhesion, and exhibits some functions as an anti-stress, antioxidant, anti-pyretic and antiinflammatory agent (GarciaGomez et al. 2000).

The development of magnesium industry in some regions in Slovakia (e.g., JelšavaLubeník) or abroad increases the risk of oversupply of magnesium from magnesium fly ash in farm and wild animals as well. Exposure of laboratory animals to magnesium fly ash results in depression of fertility, reduced numbers of offspring, and decreased weight of the visceral organs in weaned animals (Bíreš et al. 1994).

Cadmium is an essential microelement. Cadmium deficiency in ruminants leads to depression of milk production, growth retardation in young animals, muscle weakness, reluctance to move or even death. Increased concentration of cadmium in the body is toxic. The toxic effect of cadmium arises from its ability to bind to protein by thiol groups. Its toxicity depends on dosage, way of administration, form, length of exposure and animal species (Pribilincová et al. 1995). Results from our study indicate 
that cadmium was found to inhibit urease, glutamate dehydrogenase and gammaglutamyltransferase, and on the other hand it appeared to stimulate each transaminase activity tested. We proposed that the stimulatory effect of cadmium on both transaminase activities is a result of damage to the bacterial membrane by cadmium that could lead to release of enzymes tested into the rumen fluid.

Rumen urease hydrolyzes feed and endogenous urea to a form of nitrogen that can be used by most rumen microorganisms. Many papers have dealth with the study of the effectiveness of various inhibitors on the activity of rumen urease. Reducing the rate of ammonia nitrogen release from dietary urea would its utilization in ruminants (Bod'a and Várady 1966; Ludden et al. 2000a; Musalia et al. 2000; Prasad et al. 1999). But the rumen microflora may often be capable of adapting to chronic administration of urease inhibitors, thereby limiting its practical use in improving the utilization of dietary urea (Ludden et al. 2000b). Our results showed that both cadmium and copper appeared to be inhibitory for urease activity. Similar results were found by Fahmy et al. (1998) who described the effectiveness of heavy metals as inhibitors of the camel rumen urease at the concentration of $0.005 \mathrm{mM}$ was, in decreasing order $\mathrm{Hg}^{2+}>\mathrm{Cu}^{2+}>\mathrm{Zn}^{2+}>\mathrm{Ni}^{2+}>\mathrm{Co}^{2+}$ with 97 , 94, 90, 61 and 7\% inhibition, respectively.

Copper is an essential element required for the goat and other species for a number of biochemical functions. Copper stimulates growth in swine and alters lipid metabolism in steer (Engle and Spears 2000). Results of Odenkirchen et al. (1994) showed that $2 \mathrm{~g}$ $\mathrm{CuSO}_{4}$ per animal per day is recommended as the maximum dose in cattle to overcome copper deficiency. Ingestion of quantities of $\mathrm{Cu}$ sligthly higher than required may cause accumulation in the tissues and haemolysis. Sheep are more sensitive to high copper supplementation than other farm animals.

Our results showed that copper was found to inhibit both urease and glutamate dehydrogenase activities. The experiment of Wallace and McKain (1996) with Prevotella ruminicola, an organism playing a prominent role in the breakdown of peptides in the rumen showed that copper, chromium, and mercury were the most inhibitory ones, decreasing $\mathrm{Ala}_{2}$ breakdown to 15,15 and $5 \%$ of control activity, whereas cobalt, manganese and zinc stimulated activity by 189,30 and $26 \%$, respectively. The principal source of air, soil and water contamination by copper is caused by copper and iron manufacture. Cadmium gets into the environment from iron foundries. Cadmium and copper, released into athmosphere, finally accumulate in the soil and water and enter the food chain.

The results of this experiment indicate that the metal ions copper, cadmium, and magnesium affect the activity of several rumen enzymes, playing important roles in metabolism of nitrogenous compounds. They can further alter nitrogen metabolism in the rumen.

\section{Vplyv vybraných kovových prvkov na aktivitu niektorých enzýmov v bachorovej tekutine}

$\mathrm{V}$ in vitro pokusoch sme sledovali vplyv niektorých kovových iónov na aktivitu ureázy, alanín aminotransferázy-ALT, aspartát aminotransferázy-AST, gammaglutamyltransferázy-GGT and glutamát dehydrogenázy-GDH. Bachorový obsah bol odobratý od 8 fistulovaných oviec a prefiltrovaný cez gázu. Horčík, med’ a kadmium boli jednotlivo pridané do $10 \mathrm{ml}$ bachorovej tekutiny tak, aby ich výsledné koncentrácie boli $5 \mathrm{mmol} \cdot \mathrm{l}^{-1}$. Po pridaní jednotlivých kovových prvkov zmes bola premiešaná a inkubovaná 30 minút pri $37{ }^{\circ} \mathrm{C}$. Potom bola meraná enzymatická aktivita spektrofotometrickou metódou. Kadmium signifikantne inhibovalo aktivitu ureázy, GDH a GGT a na druhej strane signifikantne stimulovalo enzymatickú activitu ALT a AST. Med'signifikantne inhibovala enzymatickú aktivitu GDH a ureázy a neovplyvnila aktivity ALT, AST a GGT. Horčík stimuloval enzymatickú aktivitu GGT a GDH. Výsledky tohto experimentu 
naznačujú, že jednotlivé prvky horčík, med’ a kadmium ovplyvňujú aktivitu niektorých enzýmov v bachorovej tekutine, ktoré zohrávajú dôležitú úlohu v metabolizme dusíkatých látok, a tak môžu menit dusíkový metabolizmus v bachore oviec.

\section{Ackowledgements}

This study was partially supported by grants No. 1/8944/01 and No. 2/7028/20 from Grant Agency for Science, VEGA, Slovak Republic.

\section{References}

BÍREŠ, J, BARTKO, P, MICHNA, A, WEISSOVÁ, T, BÍREŠOVÁ, M, JENČÍK, F 1994: Klinicko-biochemické aspekty zátaže jalovíc magnezitovým úletom. Vet Med Praha 39: 355-376

BOD̃A, K, VÁRADY, J 1966: Inhibition of the rumen urease and its influence on $\mathrm{NH}_{3}$ utilization. Vet Med Praha 39: $695-702$

ENGLE, TE, SPEARS, JW 2000: Effect of dietary copper concentration and source on performance and copper status of growing and finishing steers. J Anim Sci 78: 2446-2451

FAHMY, AS, ABADIR, NY, ABD-ALLA, BM 1998: Purification and characterization of urease from the ruminal fluid of camel (Camelus dromedarius). J Camel Pract Res 5: 143-155

GARCIA-GOMEZ, F, WILLIAMS, PA, AUMAITRE, A, LEE, BD, HA, JK 2000: Magnesium metabolism in ruminant animals and its relationship to other inorganic elements. Proceedings of the 2000 International Symposium: Recent Advances in Animal Nutrition, Seoul, Korea, 20-22 April 2000. Asian-Austr J Anim Sci 13: $158-170$

JENČÍK, F, BÍREŠ, J, BINDAS, P, DANKOVČÍKOVÁ, Z, LEŠNÍK, F, MARIŠČÁKOVÁ, R, UCEKAJ, N,

BULECA, J 2001: Transport of risky mineral elements from the soil into the plant biomass II. $X^{\text {th }}$ sciencetific symposium, Hrádok, 13-14 December 2001. Proceedings of scientific symposium On Ecology in Selected Agglomerations of Jelšava-Lubeník and Central Spiš, 41-45

LEGATH, J, KAČMÁR, P, TOMÁS̆, J 1990: Changes in the amino acid concentrations of bacteria adhering to the ruminal epithelium of sheep after the oral administration of extremely low doses of mercury. Vet Med Praha 35: 657-665

LUDDEN, PA, HARMON, DL, LARSON, BT, AXE, DE 2000a: Influence of the novel urease inhibitor N-(nbutyl)thiophosphoric triamide on ruminant nitrogen metabolism: I. In vitro urea kinetics and substrate digestion. J Anim Sci 78: 181-187

LUDDEN, PA, HARMON, DL, HUNTINGTON, GB, LARSON, BT, AXE, DE 2000b: Influence of the novel urease inhibitor $\mathrm{N}$-(n-butyl)thiophosphoric triamide on ruminal nitrogen metabolism: II. Ruminal nitrogen metabolism, diet digestibility, and nitrogen balance in lambs. J Anim Sci 78: 188-198

MEHREZ, Z, ØRSKOV, ER, McDONALD, I 1977: Rates of rumen fermentation in relation to ammonia concentration. Brit J Nutr 38: 433-441

MUSALIA, LM, ANANDAN, S, SASTRY, VRB, AGRAWAL, DK 2000: Urea-treated neem (Azadirachta indica A.juss) seed kernel cake as a protein supplement for lambs. Small Anim Res 35: 107-116

ODENKIRCHEN, S, HOLTERSCHINKEN, M, SCHOLTZ, H 1994: Auswirkungen oral zu verabreichender Therapeutika auf Fermentationsvorgange im Pansensaff ruminierender Rinder (in vitro). 6. Mitteilung: Kupfersulfat. Dtsche Tierarzt Wchst 101: 16-18

PAL, DT, KAMRA, DN, PATHAK, NN, BISHT, GS 1998: Influence of rumen ciliate protozoa and protein level on rumen fermentation, enzyme activities and blood metabolites in crossbred cattle calves. J App Anim Res 13: 153-159

PRASAD, K, SAHU, DS, NAGWAL, IS, PRASAD, K 1999: Effect of defaunation and two levels of protein on rumen fermentation pattern and enzyme activity in crossbred bullocks. Ind J Anim Nutr 16: 248-251

PRIBILINCOVÁ, J, MARETTA, M, JANOTÍKOVÁ, I, MARETTOVÁ, E 1995: The effect of cadmium treatment on breeding hens and cocks and early viability of their chickens. Vet Med-Czech 40: 353-357

SPEARS, JW, HATFIELD, EE 1978: Nickel for ruminants. I. Influence of dietary nickel on ruminal urease activity. J Anim Sci 47: 1345-1350

VETH, MJDE, KOLVER, ES, DE VETH, MJ, COTTLE, D 1999: Pasture digestion in response to change in ruminal pH. $59^{\text {th }}$ conference, Holy Cross College, Mosgiel, 28 June-1 July 1999. Proceedings of the New Zealand Society of Animal Production 59: 66-69

WALLACE, RJ, McKAIN, N 1996: Influence of 1,10 phenanthroline and its analogues, other chelators and transition metal ions on dipeptidase activity of the rumen bacterium, Prevotella ruminicola. J Appl Bact 81: 42-47 